\title{
Isoptericola chiayiensis sp. nov., isolated from mangrove soil
}

\author{
Correspondence \\ M. Tseng \\ tjm@firdi.org.tw
}

\author{
M. Tseng, H. C. Liao, W. P. Chiang and G. F. Yuan \\ Bio-resource Collection and Research Center, Food Industry Research and Development Institute, \\ HsinChu, 30052, Taiwan, ROC
}

\begin{abstract}
A novel actinomycete, designated strain $06182 \mathrm{M}-1^{\top}$, was isolated from a mangrove soil sample collected from Chiayi County in Taiwan. Phylogenetic analysis based on 16S rRNA gene sequences revealed levels of similarity of 97.0-98.8\% to the type strains of recognized species of the genus /soptericola. Chemotaxonomic data also supported the placement of strain $06182 \mathrm{M}-$ $1^{\top}$ within the genus /soptericola. However, the low levels of DNA-DNA relatedness between the novel strain and the type strains of recognized species of the genus /soptericola, in combination with differential phenotypic data, demonstrate that strain $06182 \mathrm{M}-1^{\top}$ represents a novel species of the genus Isoptericola, for which the name Isoptericola chiayiensis sp. nov. is proposed. The type strain is $06182 \mathrm{M}-1^{\top}\left(=\mathrm{BCRC} 16888^{\top}=\mathrm{KCTC} 19740^{\top}\right)$.
\end{abstract}

The genus Isoptericola was proposed by Stackebrandt et al. (2004) with the reclassification of Cellulosimicrobium variabile (Bakalidou et al., 2002). At the time of writing, the genus Isoptericola comprises five recognized species (Stackebrandt et al., 2004; Groth et al., 2005; Zhang et al., 2005; Wu et al., 2010). Members of the genus are aerobic to microaerophilic organisms with a well-developed primary mycelium that fragments into short, irregular, non-motile rods and cocci. They are Gram-positive and non-acidalcohol-fast. The peptidoglycan type is $\mathrm{A} 4 \alpha$, containing L-Lys-L-Ala-L-Glu-D-Asp. Whole-cell sugars comprise glucose, rhamnose, galactose and mannose. The acyl type is acetyl. The predominant menaquinone is $\mathrm{MK}-9\left(\mathrm{H}_{4}\right)$, and major fatty acids are anteiso- $\mathrm{C}_{15: 0}$, iso- $\mathrm{C}_{15: 0}, \mathrm{C}_{16: 0}$, iso$\mathrm{C}_{16: 0}$ and anteiso- $\mathrm{C}_{17: 0}$. The phospholipids comprise diphosphatidylglycerol (DPG), phosphatidylglycerol (PG), phosphatidylinositol (PI), two glycolipids and two unknown phospholipids. Mycolic acids are absent. The $\mathrm{G}+\mathrm{C}$ content of the DNA is $70-72 \mathrm{~mol} \%$.

Strain $06182 \mathrm{M}-1^{\mathrm{T}}$ was isolated from a mangrove soil sample collected in Chiayi County, Taiwan, by using HV agar (Hayakawa \& Nonomura, 1987) with incubation at $30{ }^{\circ} \mathrm{C}$ for 28 days. The strain was maintained on trypticase soy agar (TSA; BBL) and as a suspension of cells in glycerol $(20 \%, v / v)$ stored at $-20{ }^{\circ} \mathrm{C}$.

Morphological characteristics of strain $06182 \mathrm{M}-1^{\mathrm{T}}$ were observed by scanning electron microscopy (S-4700; Hitachi), following incubation on TSA plates for 3 days at $30{ }^{\circ} \mathrm{C}$, fixation with $4 \%$ osmium tetroxide solution,

Abbreviations: DPG, diphosphatidylglycerol; PG, phosphatidylglycerol; $\mathrm{PI}$, phosphatidylinositol.

The GenBank/EMBL/DDBJ accession number for the 16S rRNA gene sequence of strain $06182 \mathrm{M}-1^{\top}$ is FJ469988. dehydration in an ethanol series followed by acetone, and critical-point drying (Itoh et al., 1989). All physiological tests were performed at $30{ }^{\circ} \mathrm{C}$. Growth temperature, hydrolysis of adenine, aesculin, casein, hypoxanthine, Ltyrosine and xanthine, and production of amylase, nitrate reductase, urease and melanin were assessed according to the methods of Gordon et al. (1974). Sole carbon source utilization was tested by using the method of Shirling \& Gottlieb (1966).

Biomass for chemotaxonomic studies was prepared following growth in shake flasks (125 r.p.m.) of trypticase soy broth (TSB; BBL) at $30{ }^{\circ} \mathrm{C}$ for 3 days. The isomer of diaminopimelic acid and sugars in whole-cell hydrolysates were determined according to Hasegawa et al. (1983). The presence of mycolic acids was examined by TLC following Minnikin et al. (1975), and phospholipids were extracted and identified following the method of Minnikin et al. (1984). Menaquinones were extracted and purified according to the method of Collins et al. (1977) and were then analysed by HPLC (model 600; Waters) with a Nova-Pak C18 column. For quantitative analysis of the cellular fatty acid content, strain $06182 \mathrm{M}-1^{\mathrm{T}}$ was cultured in TSB at $30{ }^{\circ} \mathrm{C}$ on a shaking incubator for 3 days at 125 r.p.m. Extracts of the methylated fatty acids were prepared according to the protocol provided by the manufacturer.

For extraction of DNA for sequencing of the 16S rRNA gene, strain $06182 \mathrm{M}-1^{\mathrm{T}}$ was grown in $\mathrm{TSB}$ at $30{ }^{\circ} \mathrm{C}$ for 3 days. Cells were removed from the broth by using a pipette tip and total DNA was extracted by using a Qiagen genomic DNA kit. The $\mathrm{G}+\mathrm{C}$ content of the DNA was determined by the HPLC method of Tamaoka \& Komagata (1984). DNA was prepared by using the same method as above. The 16S rRNA gene was PCR-amplified by using the methods of Nakajima et al. (1999) and was directly 


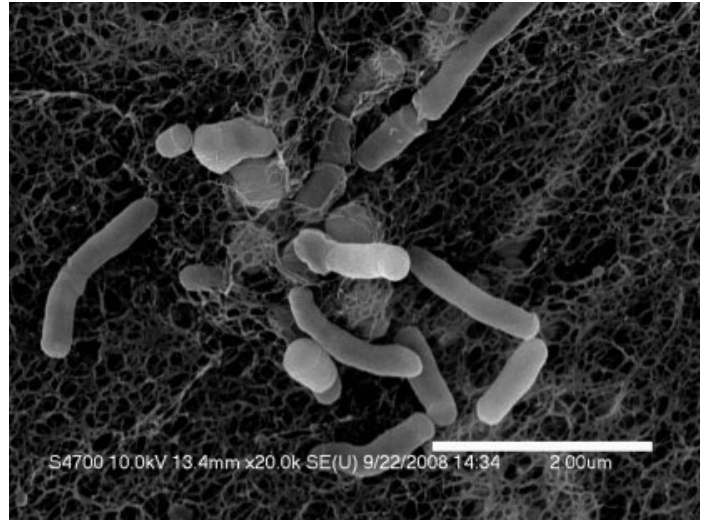

Fig. 1. Morphological characteristics of strain $06182 \mathrm{M}-1^{\top}$ grown on TSA for 3 days. Bar, $2 \mu \mathrm{m}$.

sequenced on an ABI model 3730 automatic DNA sequencer by using a BigDye Terminator V3.1 kit (Applied Biosystems). Phylogenetic analysis was performed by using the software packages PHYLIP (Felsenstein, 1993) and MEGA version 4.0 (Tamura, et al., 2007) after multiple alignments of the data by using CLUSTAL X (Thompson et al., 1997). Calculation of evolutionary distances (distance options according to the Kimura two-parameter model; Kimura, 1980, 1983) and clustering were conducted by using the neighbour-joining method (Saitou \& Nei, 1987). Bootstrap analysis was used to evaluate the tree topology of the neighbour-joining data by performing 1000 resamplings (Felsenstein, 1985). DNA-DNA hybridization was carried out according to the method of Ezaki et al. (1989).

Growth of strain $06182 \mathrm{M}-1^{\mathrm{T}}$ was aerobic and cells stained Gram-positive. Strain $06182 \mathrm{M}-1^{\mathrm{T}}$ produced substrate mycelia but no aerial mycelia. The substrate mycelia fragmented into short, irregular, non-motile rods and cocci (diameter $0.2 \mu \mathrm{m}$ ) (Fig. 1). The colour of colonies on various media was light orange-yellow. No soluble pigment was produced in any of the media tested. The results of physiological and biochemical tests are given in the species description below and in Table 1 .

Strain $06182 \mathrm{M}-\mathrm{1}^{\mathrm{T}}$ had peptidoglycan type $\mathrm{A} 4 \alpha$, comprising L-Lys-L-Ala-L-Glu-D-Asp, and glucose, galactose and rhamnose in whole-cell hydrolysates. The predominant menaquinones were MK-9 $\left(\mathrm{H}_{4}\right)$ and MK-9 $\left(\mathrm{H}_{2}\right)$; mycolic acids were not detected. DPG, PG, PI, two glycolipids and two unknown phosphoglycolipids were detected. The major fatty acid methyl esters were iso- $\mathrm{C}_{16: 0}(14.82 \%)$, $\mathrm{C}_{16: 0}(14.63 \%), \mathrm{C}_{17: 0}(13.79 \%)$ and 10 -methyl $\mathrm{C}_{17: 0}$

Table 1. Differential phenotypic characteristics between strain $06182 \mathrm{M}-1^{\top}$ and the type strains of recognized species of the genus Isoptericola

Strains: 1, 06182M-1 ${ }^{\mathrm{T}}$; 2, I. variabilis BCRC $16877^{\mathrm{T}}$; 3, I. halotolerans BCRC $16878^{\mathrm{T}} ; 4$, I. hypogeus BCRC $16879^{\mathrm{T}}$; 5, I. dokdonensis BCRC $16880^{\mathrm{T}}$; 6, I. jiangsuensis BCRC $16913^{\mathrm{T}}$. +/-, Variable reaction. Data from this study.

\begin{tabular}{|c|c|c|c|c|c|c|}
\hline Characteristic & 1 & 2 & 3 & 4 & 5 & 6 \\
\hline Growth temperature range $\left({ }^{\circ} \mathrm{C}\right)$ & $15-40$ & $15-40$ & $15-35$ & $15-35$ & $15-35$ & $15-35$ \\
\hline $\mathrm{NaCl}$ tolerance (\%) & 12 & 8 & 6 & 6 & 2 & 6 \\
\hline \multicolumn{7}{|l|}{ Hydrolysis of: } \\
\hline Adenine & + & + & + & + & - & - \\
\hline Casein & - & + & - & + & - & - \\
\hline Aesculin & + & + & + & + & + & $+1-$ \\
\hline Hippurate & + & + & + & + & - & - \\
\hline Hypoxanthine & - & + & - & + & - & - \\
\hline Milk & + & + & + & - & + & - \\
\hline Tyrosine & - & + & - & $+1-$ & - & - \\
\hline Xanthine & - & + & - & + & - & - \\
\hline Nitrate reductase & - & + & - & + & + & + \\
\hline \multicolumn{7}{|l|}{ Carbon source utilization } \\
\hline Arabinose & - & + & + & + & - & - \\
\hline Cellobiose & + & + & + & + & + & - \\
\hline Fructose & + & + & + & + & + & - \\
\hline Glucose & + & + & + & + & + & - \\
\hline Inositol & - & - & - & + & - & - \\
\hline Mannitol & + & - & + & + & - & - \\
\hline Raffinose & - & + & + & - & - & - \\
\hline Rhamnose & + & - & - & + & + & - \\
\hline Sucrose & + & - & + & + & + & - \\
\hline Xylose & + & - & + & + & + & - \\
\hline
\end{tabular}


Table 2. Fatty acid profiles of strain $06182 \mathrm{M}-1^{\top}$ and the type strains of recognized Isoptericola species

Strains: 1 , 06182M-1 ${ }^{\mathrm{T}} ; 2$, I. variabilis BCRC $16877^{\mathrm{T}} ; 3$, I. halotolerans BCRC $16878^{\mathrm{T}}$; 4, I. hypogeus BCRC $16879^{\mathrm{T}}$; 5 , I. dokdonensis BCRC $16880^{\mathrm{T}} ; 6$, I. jiangsuensis BCRC $16913^{\mathrm{T}}$. Values are percentages of the total fatty acids. Data from this study.

\begin{tabular}{|c|c|c|c|c|c|c|}
\hline Fatty acid & 1 & 2 & 3 & 4 & 5 & 6 \\
\hline $\mathrm{C}_{14: 0}$ & 1.75 & 2.18 & 1.28 & 2.97 & 3.09 & 2.92 \\
\hline$C_{16: 0}$ & 9.72 & 3.39 & 17.63 & 3.70 & 8.97 & 8.11 \\
\hline $\mathrm{C}_{17: 0}$ & 1.48 & 0.16 & 0.97 & 0.17 & 1.16 & 1.94 \\
\hline iso- $\mathrm{C}_{13: 0}$ & & & & & 1.29 & 3.04 \\
\hline iso- $\mathrm{C}_{14: 0}$ & 3.01 & 1.93 & 0.50 & 1.17 & 2.54 & 3.55 \\
\hline iso- $\mathrm{C}_{15: 0}$ & 12.02 & 20.11 & 4.46 & 15.65 & 11.28 & 10.75 \\
\hline iso- $\mathrm{C}_{16: 0}$ & 5.02 & 10.16 & 1.93 & 3.45 & 1.93 & 2.39 \\
\hline iso- $\mathrm{C}_{17: 0}$ & 1.37 & 1.24 & 0.92 & 0.65 & 0.63 & 0.96 \\
\hline anteiso- $\mathrm{C}_{15: 0}$ & 55.04 & 50.70 & 53.62 & 61.77 & 61.98 & 56.49 \\
\hline anteiso- $\mathrm{C}_{17: 0}$ & 8.77 & 10.02 & 18.01 & 10.11 & 5.61 & 7.45 \\
\hline
\end{tabular}

(23.77\%) (Table 2). The $\mathrm{G}+\mathrm{C}$ content of the DNA of strain $06182 \mathrm{M}-1^{\mathrm{T}}$ was $72.8 \mathrm{~mol} \%$.

The almost-complete $16 \mathrm{~S}$ rRNA gene sequence (1514 nt) of strain $06182 \mathrm{M}-1^{\mathrm{T}}$ was determined. Preliminary comparison of the 16S rRNA gene sequence of strain $06182 \mathrm{M}$ $1^{\mathrm{T}}$ against the GenBank database revealed high levels of similarity with the type strains of recognized species of the genus Isoptericola: Isoptericola dokdonensis BCRC $16880^{\mathrm{T}}$ (97.9\%), Isoptericola halotolerans BCRC $16878^{\mathrm{T}}$ (98.8\%), Isoptericola hypogeus BCRC $16879^{\mathrm{T}}(97.0 \%)$, Isoptericola jiangsuensis BCRC $16913^{\mathrm{T}}(98.0 \%)$ and Isoptericola variabilis BCRC $16877^{\mathrm{T}}$ (97.9\%). The neighbour-joining phylogenetic tree based on 16S rRNA gene sequences of strain $06182 \mathrm{M}-1^{\mathrm{T}}$ and the type strains of recognized species of the genus Isoptericola and other related species is shown in Fig. 2. DNA-DNA hybridization experiments revealed that levels of DNA-DNA relatedness between strain $06182 \mathrm{M}-1^{\mathrm{T}}$ and the type strains of recognized species of the genus Isoptericola were relatively low: I. dokdonensis BCRC $16880^{\mathrm{T}}(16.7 \%)$, I. halotolerans BCRC $16878^{\mathrm{T}}$ (16.8\%), I. hypogeus BCRC $16879^{\mathrm{T}}$ (8.8\%), I. jiangsuensis BCRC $16913^{\mathrm{T}}(15.4 \%)$ and $I$. variabilis BCRC $16877^{\mathrm{T}}$
(5.3\%). These values are below the $70 \%$ cut-off point recommended for the assignment of organisms to the same species (Wayne et al., 1987). The phylogenetic data thus indicate that strain $06182 \mathrm{M}-1^{\mathrm{T}}$ represents a novel species, which is confirmed by comparison of phenotypic characteristics with those of the type strains of recognized species of the genus Isoptericola (Table 1). Therefore, on the basis of the phenotypic and genotypic data presented, strain $06182 \mathrm{M}-1^{\mathrm{T}}$ is considered to represent a novel species of the genus Isoptericola, for which the name Isoptericola chiayiensis sp. nov. is proposed.

\section{Description of Isoptericola chiayiensis sp. nov.}

Isoptericola chiayiensis (chia.yi.en'sis. N.L. masc. adj. chiayiensis of Chiayi County, from where the type strain was isolated).

Cells are Gram-positive and aerobic. Produces substrate mycelia but no aerial mycelia. Substrate mycelia fragment into short, irregular, non-motile rods and cocci (diameter $0.2 \mu \mathrm{m})$. The colour of colonies on various media is light orange-yellow; no soluble pigment is produced. Growth occurs between 15 and $40{ }^{\circ} \mathrm{C}$ (optimal growth at $30{ }^{\circ} \mathrm{C}$ ). Tolerates up to $12 \%(\mathrm{w} / \mathrm{v}) \mathrm{NaCl}$ in the culture medium. Positive for adenine, aesculin, hippurate and starch hydrolysis and milk peptonization, but negative for casein, chitin, hypoxanthine, tyrosine and xanthine hydrolysis, gelatin liquefaction, and urease, melanin and nitrate reductase production. Utilizes cellobiose, fructose, glucose, mannitol, rhamnose, sucrose and xylose, but not arabinose, inositol or raffinose. The peptidoglycan type is A4 $\alpha$, with LLys-L-Ala-L-Glu-D-Asp, and glucose, galactose and rhamnose in whole-cell hydrolysates. The predominant menaquinones are MK-9 $\left(\mathrm{H}_{4}\right)$ and $\mathrm{MK}-9\left(\mathrm{H}_{2}\right)$; mycolic acids are not detected. DPG, PG, PI, two glycolipids and two unknown phosphoglycolipids are detected. The major fatty acid methyl esters are iso- $\mathrm{C}_{16: 0}, \mathrm{C}_{16: 0}, \mathrm{C}_{17: 0}$ and 10-methyl $\mathrm{C}_{17: 0}$. The $\mathrm{G}+\mathrm{C}$ content of the DNA of the type strain is $72.8 \mathrm{~mol} \%$.

The type strain, $06182 \mathrm{M}-1^{\mathrm{T}}\left(=\mathrm{BCRC} 16888^{\mathrm{T}}=\mathrm{KCTC}\right.$ $19740^{\mathrm{T}}$ ), was isolated from mangrove soil collected from Chiayi County, Taiwan.

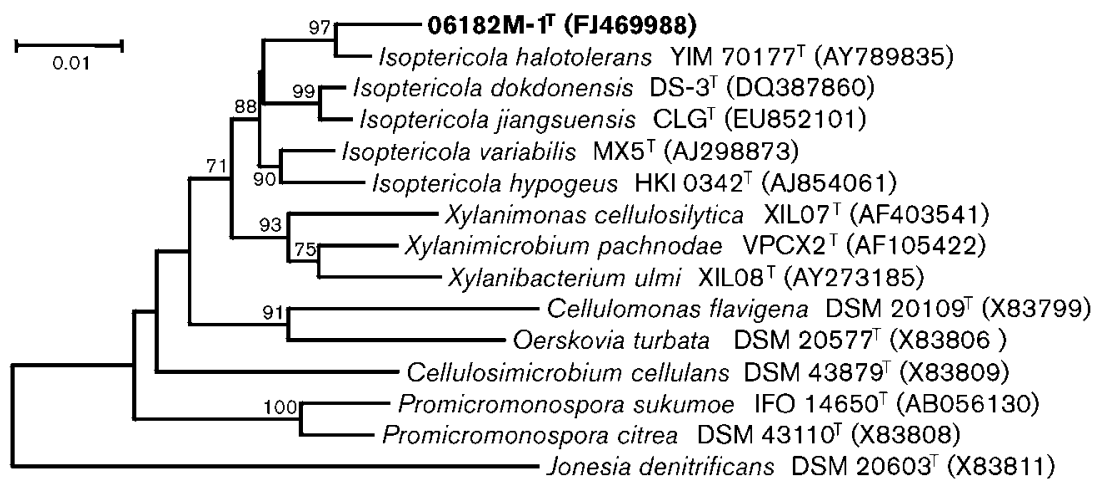

Fig. 2. Neighbour-joining phylogenetic tree based on 16S rRNA gene sequences showing the positions of strain $06182 \mathrm{M}-1^{\top}$, the type strains of recognized species of the genus Isoptericola and some other related taxa. Numbers at nodes indicate percentages of 1000 bootstrap resamplings; only values $>50 \%$ are given. Jonesia denitrificans DSM $20603^{\top}$ was used as an outgroup. Bar, 0.01 substitutions per nucleotide position. 


\section{Acknowledgements}

This research was supported partially by the Ministry of Economic Affairs, ROC (project no. 95-EC-17-A-17-R7-0525).

\section{References}

Bakalidou, A., Kämpfer, P., Berchtold, M., Kuhnigk, T., Wenzel, M. \& König, H. (2002). Cellulosimicrobium variabile sp. nov., a cellulolytic bacterium from the hindgut of the termite Mastotermes darwiniensis. Int J Syst Evol Microbiol 52, 1185-1192.

Collins, M. D., Pirouz, T., Goodfellow, M. \& Minnikin, D. E. (1977). Distribution of menaquinones in actinomycetes and corynebacteria. J Gen Microbiol 100, 221-230.

Ezaki, T., Hashimoto, Y. \& Yabuuchi, E. (1989). Fluorometric deoxyribonucleic acid-deoxyribonucleic acid hybridization in microdilution wells as an alternative to membrane filter hybridization in which radioisotopes are used to determine genetic relatedness among bacterial strains. Int J Syst Bacteriol 39, 224-229.

Felsenstein, J. (1985). Confidence limits on phylogenies: an approach using the bootstrap. Evolution 39, 783-791.

Felsenstein, J. (1993). PHYLIP (phylogeny inference package), version 3.5c. Department of Genetics, University of Washington, Seattle, USA.

Gordon, R. E., Barnett, D. A., Handerhan, J. E. \& Pang, C. H. N. (1974). Nocardia coeliaca, Nocardia autotrophica, and the nocardin strain. Int J Syst Bacteriol 24, 54-63.

Groth, I., Schumann, P., Schütze, B., Gonzalez, J. M., Laiz, L., SaizJimenez, C. \& Stackebrandt, E. (2005). Isoptericola hypogeus sp. nov., isolated from the Roman catacomb of Domitilla. Int J Syst Evol Microbiol 55, 1715-1719.

Hasegawa, T., Takizawa, M. \& Tanida, S. (1983). A rapid analysis for chemical grouping of aerobic actinomycetes. J Gen Appl Microbiol 29, 319-322.

Hayakawa, M. \& Nonomura, H. (1987). Humic acid-vitamin agar, a new medium for the selective isolation of soil actinomycetes. J Ferment Technol 65, 501-509.

Itoh, T., Kudo, T., Parenti, F. \& Seino, A. (1989). Amended description of the genus Kineosporia, based on chemotaxonomic and morphological studies. Int J Syst Bacteriol 39, 168-173.

Kimura, M. (1980). A simple method for estimating evolutionary rates of base substitutions through comparative studies of nucleotide sequences. J Mol Evol 16, 111-120.

Kimura, M. (1983). The Neutral Theory of Molecular Evolution. Cambridge: Cambridge University Press.
Minnikin, D. E., Alshamaony, L. \& Goodfellow, M. (1975). Differentiation of Mycobacterium, Nocardia, and related taxa by thin-layer chromatographic analysis of whole-organism methanolysates. J Gen Microbiol 88, 200-204.

Minnikin, D. E., O’Donnell, A. G., Goodfellow, M., Alderson, G., Athalye, M., Schaal, A. \& Parlett, J. H. (1984). An integrated procedure for extraction of bacterial isoprenoid quinones and polar lipids. J Microbiol Methods 2, 233-241.

Nakajima, Y., Kitpreechavanich, V., Suzuki, K. \& Kudo, T. (1999). Microbispora corallina sp. nov., a new species of the genus Microbispora isolated from Thai soil. Int J Syst Bacteriol 49, 17611767.

Saitou, N. \& Nei, M. (1987). The neighbor-joining method: a new method for reconstructing phylogenetic trees. Mol Biol Evol 4, 406425.

Shirling, E. B. \& Gottlieb, D. (1966). Methods for characterization of Streptomyces species. Int J Syst Bacteriol 16, 313-340.

Stackebrandt, E., Schumann, P. \& Cui, X.-L. (2004). Reclassification of Cellulosimicrobium variabile Bakalidou et al. 2002 as Isoptericola variabilis gen. nov., comb. nov. Int J Syst Evol Microbiol 54, 685-688.

Tamaoka, J. \& Komagata, K. (1984). Determination of DNA base composition by reversed-phase high-performance liquid chromatography. FEMS Microbiol Lett 25, 125-128.

Tamura, K., Dudley, J., Nei, M. \& Kumar, S. (2007). MEGA4: molecular evolutionary genetics analysis (MEGA) software version 4.0. Mol Biol Evol 24, 1596-1599.

Thompson, J. D., Gibson, T. J., Plewniak, F., Jeanmougin, F. \& Higgins, D. G. (1997). The CLUSTAL_X windows interface: flexible strategies for multiple sequence alignment aided by quality analysis tools. Nucleic Acids Res 25, 4876-4882.

Wayne, L. G., Brenner, D. J., Colwell, R. R., Grimont, P. A. D., Kandler, O., Krichevsky, M. I., Moore, L. H., Moore, W. E. C., Murray, R. G. E. \& other authors (1987). International Committee on Systematic Bacteriology. Report of the ad hoc committee on reconciliation of approaches to bacterial systematics. Int $J$ Syst Bacteriol 37, 463-464.

Wu, Y., Li, W.-J., Tian, W., Zhang, L.-P., Xu, L., Shen, Q.-R. \& Shen, B. (2010). Isoptericola jiangsuensis sp. nov., a chitin-degrading bacterium. Int J Syst Evol Microbiol 60, 904-908.

Zhang, Y. Q., Schumann, P., Li, W. J., Chen, G. Z., Tian, X. P., Stackebrandt, E., Xu, L. H. \& Jiang, C. L. (2005). Isoptericola halotolerans sp. nov., a novel actinobacterium isolated from saline soil from Qinghai Province, north-west China. Int J Syst Evol Microbiol 55, 1867-1870. 